\title{
WEEKEND TOURISM AND UNPLANNED CONSTRUCTION IN DELIBLATO SANDS
}

\author{
Marina Vesić ${ }^{* 1}$ \\ "University of Belgrade - Faculty of Geography, Belgrade
}

\begin{abstract}
On sites of former Deliblato Sands' vineyards, the present-day weekend settlements have been built. Devojački bunar is the most frequently visited one among them and it has the longest and the most significant touristic tradition which includes the largest number of weekend homes for resting and recreation (even 1.392 , according to the latest registration). Considering the special quality and ecological significance of Deliblato Sands that enable development of numerous selectable forms of tourism (among which is the weekend tourism), it is necessary to reflect about the factors that are the bases of touristic movements: those are attractiveness, accessibility and residing conditions of the site itself. This paper treats the problem of interconnection of unplanned (illegal) construction of weekend homes (meaning dwelling conditions) and development of weekend tourism, together with a given overview of the existing weekend settlements in the territory of five municipalities that have a share in Special Nature Reserve (SNR) "Deliblato Sands". A comparative analysis has been used, based on the data gathered from Republic Statistical Office of Serbia for the registration periods of 1981-2011.
\end{abstract}

Key words: weekend tourism, special nature reserve, sustainable development, unplanned construction, Deliblato Sands.

${ }^{1}$ Corresponding author: M. Vesić, University of Belgrade - Faculty of Geography, Studentski trg 3/III, 11,000 Belgrade, Serbia; e-mail: marinailincic@gmail.com 


\section{Introduction}

Current migration (circulation) from a place of permanent residence to a weekend home does not mean diverging from the usual way of life, but presents a normal part of a modern life style - "style of a travelling-mankind" (Adamiak, Pitkanen and Lehtonen, 2017) which denotes the fact that a weekend tourism has become one of the predominant forms of tourism.

Although a term "weekend home" originally referred to houses intended for spare-time resting and recreation during a day, gradually the term has come to encompass the objects of secondary recreational residences which are also used for longer stays throughout the weekend, longer holidays or even throughout longer period of a year. Regarding this, if a classifying criterion becomes frequency of departing and a staying period at the weekend-home, housing units for resting and recreation can be divided into: facilities for everyday use during a day (after working hours); objects for use during weekends and shorter holidays (weekend-homes in the narrow sense of the word; i.e. weekend homes); objects used during a specific season/vacation time (vacation homes); objects used during longer periods of the year (implying a function of a dual residence and eventually, a place of permanent residence "in the old days"-future permanent home).Hence, when considering the length of the tourists staying in them, we can conclude that weekend tourism implies staying at a specific touristic destination, from Friday afternoon till Sunday evening.

The basic purpose of the weekend zone is an occasional residing and staying throughout weekend, and even the following content is possible: rural tourism, service and craftwork activities in the function of tourism, wine cellars, hobby gardens, green areas etc (Просторни план општине Алибунар, 2012:145). Velvin et al., (2013) have developed and suggested a model which consists of socio-economic factors and factors that are connected to weekend -homes study and they have come to the results that explain the significance and impact of weekend tourism on the local economic growth. Adamiak, Pitkanen and Lehtonen, (2017) point out that secondary residencies (weekend-homes) create various relationships between urban and rural (protected) areas and that they create socio-economic potential primarily for rural areas. Nevertheless, they point out that such construction has to be exclusively planned one, lest it bring more harm than good to these areas.

Uncontrolled construction, i.e. illegal construction of weekend-homes on the protected-natural-resource areas can bring about numerous negative con- 
sequences, primarily considering the fact that by inadequate construction the flora and fauna that represent the founding value of SRN "Deliblato Sands", and on which the touristic migrations are based, can become misbalanced.

Our domestic legislation does not recognize the term "wild-unplanned construction" in public registers, while the term "illegal construction" refers to unclear/incomplete rights to land-use and/or tax malfeasances. Illegal or uncontrolled construction refers to the construction without construction permit i.e. the one that cannot be approved, because the matter in question is construction without the prescribed legal and technical documentation (http:/ / www.pur.rs/). Brida, Osti and Santifaller, (2011) indicate that one of the main problems of such a construction type in protected natural estates is its incompatibility with the natural surroundings, in the sense of inadequate construction-materials use, which leads to disruption of harmony, but also to the fundamental natural values of space. The main issue with this type of construction refers to the fact that while the construction itself is in process, the owners of the weekend-homes often present the urban life style and urban values which are being temporarily transferred to the environment with different norms and values which, in most cases, may cause a discrepancy with the local life style (Farstad, 2013; Farstad, Ryeab, 2013). Kodermann, (2017) indicates that although there were attempts of reconstruction of many objects of this type in Slovenia's area, they are not adjusted to the traditional architecture or norms defined by the Law on Protected Natural Resources. His stance is that these objects have largely contributed to the transformation of traditional Alpine scenery and partial loss of identity of this area. According to Hiltunen et al., 2013; Hall, 2014; Winkler, Deller and Marcouiller, 2015, impact of weekend tourism and possession of secondary residence for relaxation brought about differences with regards to national and local features of each destination.

Deliblato Sands presents a unique phenomenon of nature in whole of Europe and an unusual combination of sand, steppe, forest and marsh vegetation, extraordinary in the Pannonian Plain, because of which it was proclaimed to be a special reserve of nature and it is under protection of UNESCO. Within its frames there are 2 strictly natural reserves, 16 reserves of genetic stock funds and 6 monuments of nature. Deliblato Sands is located in the south-east part of Vojvodina, on the territory of five municipalities: Kovin, Pančevo, Alibunar, Vršac and Bela Crkva. It is renowned as a destination of ecotourism, educational, recreational and hunting tourism and as a secondary residence-weekend tourism (Просторни план подручја посебне намене Специјалног резервата природе Делиблатска пешчара 2006; Kovačev et al. 2014). As well as many other natural resources in Serbia, Deliblato Sands 
is confronted with problems of unplanned weekend-homes construction on touristically attractive and ecologically valuable areas. The objective is to find out to which extent and in which parts of protected areas exist the most developed ones affected by weekend-tourism and what mirrors the negative impact of unplanned construction on the protected territories. The aim is also to indicate the basic requirements that must be met in order to establish planned construction objects designed for development of this kind of tourism.

\section{Previous research}

Analysis of world literature in English we can see that for resting and recreational objects (vikendice in Serbian speaking area) different names are used: second home, second residence, second dwelling, recreational home, holiday home (especially popular term in Australia), vacation home, summer house, vacation cottage (most commonly used in forest areas of Canada and the United States), summer cottage, recreational cottage, hut, shack, cabin, mansion house, summer villas, marine villas (Australia), bach, crib (New Zealand), recreational vehicle, recreation boat, timesharing, caravan, and so on. German literature shows that the most common terms are: zweitwohnung, ferienhaus, freizeitwohnung, ommerhaus, which indicate the fact that the founding concept of weekend-housing stems from its broader social and psychological connotation, from its basic purpose, or from the morphological features of the object wherein it is placed. The terminology used in French language are: résidence secondaire, maison de vacances, and in Spanish language those are: residencia secundaria, vivienda secundaria (Charles-Edwards, Bell, 2015; Marjavaara, Lundholm, 2016; Back, Marjavaara, 2017; Lardiés-Bosque, 2017). Surrounding countries (Croatia, Bulgaria, and Macedonia) also use the term vikendica, which denotes a flat for resting and recreation or a residence/residing place for resting and recreation. Slovenian language comes with a term sekundarno počitniško bivališče (secondary residence/residing place for resting) (Koderman, 2017). Reversal in the process of urban concentration and the construction of secondary residences are interpretted as signs of reversal in dominant trends of deconcentration of population in the village-city relation with an accent on living a higherquality life-style especially in the USA and the countries of Western Europe during 70s of the 20th centurya (Adamiak, Pitkanen and Lehtonen, 2017). The results of reserarches in Croatia undertaken by (Miletić, Žmuk i Mišetić, 2017) show that secondary homes and tourism independently have positive effect on local socio-economic development. They also indicate a fact that it is previously necessary to define biological and ecological capacities of the given area 
(acceptable scope and structure of receptive capacities) lest spatial degradation might occur caused by unplanned (uncontrolled construction).

Interest in the study of resting and recreational homes in Sebia is considered to have begun at the end of the seventies of the twentieth century. Geographic representation, chronological display of weekend-housing estates development, infrastructural support, touristic significance of the estate areas have been incorporated into complex geographical researches primarily of the Mountains of Rajac, Bukulja, Kosmaj, Vlasina Lake, Gornja Trepča Spa, The Spa of Niš (Pavlović, 2017). What can be stated is that the flats for resting and recreation, touristically speaking, do not represent a clear type of accommodation. The term encompasses the accommodation with a different ownership, function and character. Generally speaking, the flats have secondary usage and recreational purpose, with predominantly lower economic significance (except for the flats rented to tourists).

\section{Methodology of research}

One of the basic contemporary issues is concerned with sustainable development of the natural, ecological systems and the living environment, especially when it comes to a protected natural resource. It is certainly in the closest connection to planning and spatial management as one of the significant factors of system sustainability as well as sustainable development of tourism.

Out of the same reason an analysis on Spatial Planning of Comprehensive Municipalities has been carried out on the Deliblato Sands Area. A comparative method has been used, based on the data gathered from Republic Statistical Office (RSO) of Serbia for the registration periods from 1981 till 2011. The necessary data have been gathered and the advantages and disadvantages of weekend-tourism development have been pointed out, while taking into consideration all material and nonmaterial advantages of a protected area. An overview of the existing weekend settlements on the territories of five municipalities which have a share in SNR "Deliblato Sands". Cartographic method has been used to indicate and draw the largest weekend settlements.

\section{Results of research and Discussion}

Special Nature Reserve "Deliblato Sands" is placed under the strictest protection regime $\left(1^{\text {st }}\right.$ category, Natural Resource of exceptional significance) 
because of which it implies strict conditions for object construction and landscaping. Spatial plan for special-purpose areas (Просторни план подручја посебне намене Специјалног резервата природе Делиблатска пешчара, 2006), defines conditions for arrangement of the existing resting-housing zones (weekend zone) within SNR "Deliblato Sands", which refer to the following:

- It is allowed to reconstruct the existing objects in order to improve the functionality, by using natural materials;

- It is necessary to cherish autochtonous species;

- It is forbidden to build fences, except for the "living fence“;

- It is allowed to reconstruct and possibly to upgrade infrastructure only for the needs of existing facilities.

The same plan implies that the construction of new resting and recreational homes (weekend-homes) can be carried out within the border parts which are defined for this purpose, based on the urbanistic plan with the corresponding regulatory development in accordance with the following conditions:

- Plot area on which the „weekend-home“ is being built cannot be less than 800 square meters;

- Only one „weekend home“ can be built on a single plot with an assissting facility which is in the function of a basic facility (a goods shed, a garage etc.);

- Total surface area of all plot facilities must be up to $10 \%$ of the total plot area;

- Floor area of the „weekend home“ can be ground floor (GF) or ground floor and loft $(\mathrm{GF}+\mathrm{L})$;

- Distance between facilities should provide a relative isolation (visual and audio) but should not be less than 10 meters;

- "Weekend homes" should be adjusted to the immediate environment and landscape;

- The fence around the plot should be hedges up to 1,50 meters high.

Planned framework for protection, using and arrangement of the exceptionally significant areas is compulsory for spatial plans of comprehensive municipalities and all urbanistic plans (housing-estates, weekend settlements, 
touristic locations). The afore planned decisions and propositions were abided by in the spatial plans made by municipality of Bela Crkva (2008), Vršac (2009), The City of Pančevo (2009), Kovin (2012) and Alibunar (2012).

To analize available resources and estimate potentials and limitations for their use for touristic development it is significant that Просторни план подручја посебне намене Специјалног резервата природе Делиблатска пешчара (2006) extends to a larger area. The protected area SNR „Deliblato Sands" (about 346 square $\mathrm{km}^{2}$ ) represents about one third of the total comprehensive area (about 1112 square $\mathrm{km}^{2}$ ) in the parts of municipality areas of Vršac, Bela Crkva, Alibunar, Kovin and the City of Pančevo. Wider territory of Spatial Plan For Special Purpose Areas of the Special Nature Reserve "Deliblato Sands" entails the total surface area of 111.196,43 ha, while the protected area of SNR "Deliblato Sands" extends to 34.609,32 ha.

Out of total 76.628,79 ha of the municipality of Pančevo City, Dolovo is the only one out of 10 settlements, which are positioned within the border part of Spatial Plan For Special Purpose Areas of the Special Nature Reserve „Deliblato Sands“ with its 11.736 ha of area, i.e. 15,51\% (Prostorni plan opštine-Grada Pančeva, 2009:15).

Просторни план општине Ковин (2012) defines weekend zones in LRM, i.e. Land-Registry Municipality of Gaj, LRM of Deliblato, LRM of Dubovac, LRM of Kovin and LRM of Mramorak. The territory of the municipality itself occupies around $63 \%$ out of the total Deliblato sands area, i.e. 220 square kilometers. The construction of new resting and recreation homes can be carried out only in zones that are planned by this Spatial Plan, based on a location permit in case when regulations are not being altered, i.e. when plots have access from the public surface area (road). Within the LRM of Mramorak restinghome zones are located on the following sites: "Dolovačka Stanica", "Stankova dolina" and "Mramorački vinogradi" are completely within the border parts of SNR “Deliblato sands” (Просторни план општине Ковин, 2012).

The balance-sheet for spatial purpose within the Просторни план општине Бела Црква (2008) shows that resting homes-weekend homes, in the year of 2005 was 434 ha, and the planned projection for 2025 will still be 434 ha. Out of Bela Crkva Municipality territory, 45\% (4989ha) is occupied by SNR "Deliblato sands", while the border part of SNR " Deliblato Sands" the weekend zone for resting homes takes up about 14\% (План генералне регулације Бела Црква-Нацрт Плана, 2016). 
Просторни план подручја посебне намене Специјалног резервата природе Делиблатска пешчара takes up 3 Land-Registry Municipalities of Vršac municipality: LRM of Šušara, LRM of Uljma and LRM of Izbište with a total surface area of $14.901,65$ ha. A part of LRM of Šušara is located within border part of SNR "Deliblato Sands", and the remaining part of LRM of Šušara, LRM of Uljma and LRM of Izbište is located within the scope of Просторни план подручја посебне намене Специјалног резервата природе Делиблатска пешчара (influential location) (Просторни план општине Вршац, 2009:8).

On the territory of Alibunar municipality, within the border parts of SNR "Deliblato Sands", resting-home-zones take up the area of 221,34 ha, while within the border part of influential locations they take up the surface area of 726,58 ha (Просторни план подручја посебне намене Специјалног резервата природе Делиблатска пешчара, 2006; Bakić et al., 2010-2011).

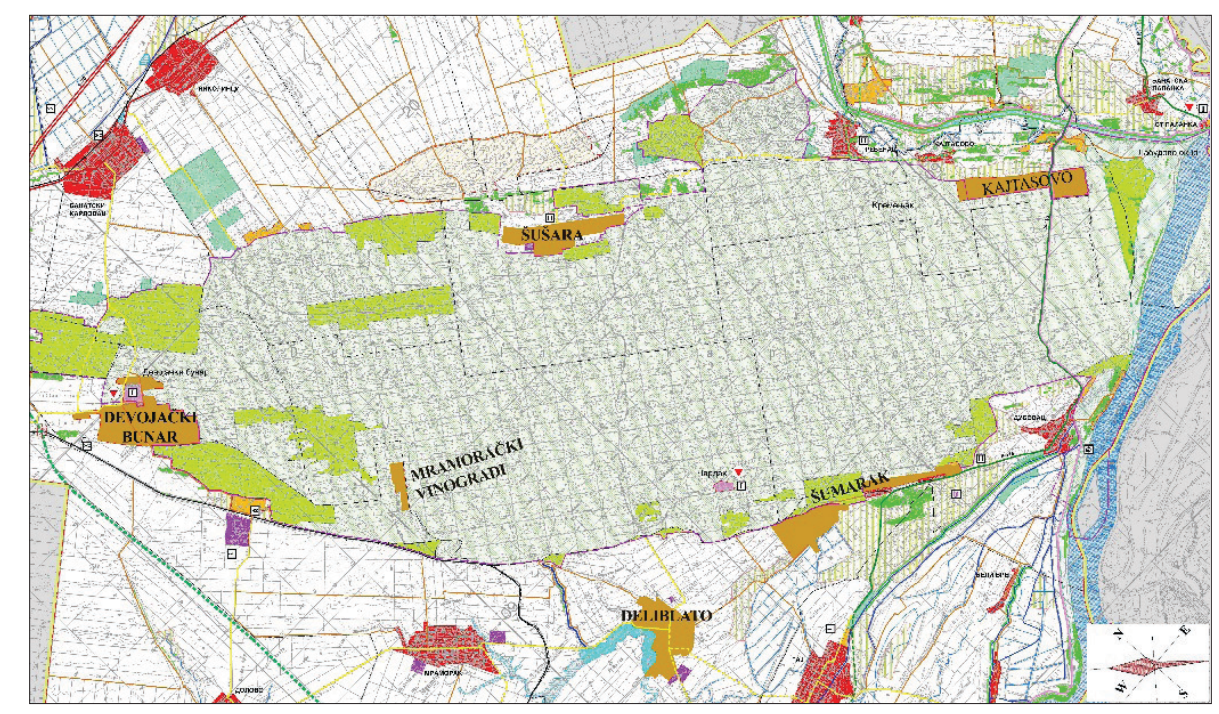

Figure 1 - Map of SNR "Deliblato Sands" with prominent weekend settlements Source: (Author, customized according to Просторни план подручја посебне намене Специјалног резервата природе Делиблатска пешчара, 2006)

Weekend settlements "Devojački bunar" is considered to be the most beautiful part of SNR "Deliblato Sands", it is a weekend settlements in the municipality of Alibunar, which does not represent a settlements formally, 
but is situated in the composition of the Banatski Karlovci settlements (it is located 7 kilometers farther away). It was built in 1895 designated as "Vekerlova kolonija" in the place which was earlier taken up by vineyard homes. This weekend settlements has 50 permanent-residing households and over 1.200 of housing units for resting and recreation (mostly weekend-homes) built up on the individual estates, whose owners are mainly residents of municipalities of Alibunar, Pančevo and Belgrade. Based on Просторни план подручја посебне намене Специјалног резервата природе Делиблатска пешчара from 2006, within the framework of "Other Significant Spatial Complexes" in the zone of 3rd degree protection regime, where the locations of "Devojački Bunar" and Čardak, the entire surface area is 53 ha, and the area of resting-homes zone is presented with 222 ha encompassing (a small part of "weekend zone" at the Palfi Colony which takes up about 25 ha of surface area, 55 ha at "Devojački Bunar" site and the other areas at the housing-projects Šumarak, Dubovac and a part of Mramorački vinogradi).

Taking into account the population registration books, i.e. the number of flats for resting and recreation, it is possible to follow the prospective changes and their spatial placement. Data, shown in the Table 1 are available for following, where the separated and the most numerous weekend settlements on the territory of SNR "Deliblato Sands" are considered, according to their affiliation to a specific municipality.

According to the data presented in the table, it can be stated that within the framework of every weekend settlements there has been an increase in the number of resting and recreational homes during the last 30 years in the registration periods from 1981-2011, except for the settlements of Deliblato in Kovin, where almost fivefold decrease in resting and recreational homes had occurred. The most numerous weekend settlements on the territory of SNR "Deliblato Sands" are mentioned within the municipality of Kovin.

Except for the aforementioned location, within the framework of SNR "Deliblato Sands", it is also possible to develop weekend tourism at the location of Čardak-Kovin municipality, through the programs of the so-called schools in the nature and residing of sporting-recreationists who would be at their preparations, tournaments etc. (ecologists, students on education) where there exists the appropriate material basis within the established Educational Center (Bakić et al., 2010-2011). 
Table 1 - The most numerous weekend settlements on a territory of a protected area

\begin{tabular}{|c|c|c|c|c|c|}
\hline $\begin{array}{l}\text { Protected Natural } \\
\text { Resource }\end{array}$ & Settlements/Municipality & \multicolumn{4}{|c|}{$\begin{array}{l}\text { Number of resting and } \\
\text { recreation homes, } \\
\text { According to Registration } \\
\text { periods }\end{array}$} \\
\hline \multirow{7}{*}{$\begin{array}{l}\text { Special } \\
\text { Nature Reserve } \\
\text { „Deliblato Sands“ }\end{array}$} & \multirow{2}{*}{$\begin{array}{l}\text { Devojački bunar } \\
\text { Municipality of Alibunar }\end{array}$} & 1981 & 1991 & 2002 & 2011 \\
\hline & & 359 & 924 & 687 & 1.392 \\
\hline & $\begin{array}{l}\text { Kajtasovo } \\
\text { Municipality of Bela Crkva }\end{array}$ & 147 & 301 & 275 & 310 \\
\hline & $\begin{array}{l}\text { Šumarak } \\
\text { Municipality of Kovin }\end{array}$ & / & 141 & 111 & 146 \\
\hline & $\begin{array}{l}\text { Mramorački vinogradi } \\
\text { Municipality of Kovin }\end{array}$ & 19 & 97 & 109 & 136 \\
\hline & $\begin{array}{l}\text { Šušara } \\
\text { Municipality of Vršac }\end{array}$ & / & 61 & 74 & 82 \\
\hline & $\begin{array}{l}\text { Deliblato } \\
\text { Municipality of Kovin }\end{array}$ & 30 & 94 & 150 & 36 \\
\hline
\end{tabular}

The only existing disadvantage is the fact that the required urbanistic plans were not produced. Among the biggest issues that may occur are the wastewaters. Uncontrolled wastewater discharge from the weekend settlements, nonexistence of wastewater filtering devices, sporadic existence of cesspits and the watercourses pollution have negative effects on flora and fauna. Erosion of the surface soil layers from the agricultural areas creates soil and watercourse pollution where the fish population is mostly endangered. According to the insights into the existing spatial plans and the reserves' conditions, the construction on touristic locations within weekendzones as well as on newly planned agricultural complexes within a protected nature reserve, must be carried out exclusively based on urbanistic plans and the corresponding regulative elaboration.

Insight into the available studies on the subject, states that the weekend-homes construction on the protected area gained characteristics of randomness both according to the number of facilities and to its functional and architectural concepts. 
Illegal-unplanned construction, in the terms of inappropriate spatial shaping, overtaking and dividing the plots, illegal connecting to the utility infrastructure and numerous other inconsistencies, annihilate the founding rationality of the spatial planning. Especially, such a manner of construction brings about decline of the founding natural values and causes their endangerment and the usual functioning, which can cause even the loss of its already existing status. Coordination of the gathered planned documentation and the documentation in-the-preparation, with the assigned natureprotection regimes for this specific area, as well as the preparation of an adequate program of permanently coordinated management, with which the needs of nature, economy (tourism, forestry, agriculture, water management etc.) and the local community (local population) would be balanced in the most convenient manner which can prevent inconsistencies among their interests, furthermore it can manage recording of all endangering factors (uncontrolled construction among others), together with defining and conducting measures for their alleviation and removal.

\section{Conclusion}

Deliblato Sands is characterized by a very suitable geographic and traffic position, because it is situated in weekend outing zone of Belgrade and in immediate vicinity of administrative, cultural and touristic centers; close the border with Romania which enables organizing daily, semi-daily, and weekend picnics. High level of its health and recreational functionality of natural elements, ecologic, landscape-features of the wider area, form foundation values for better development of this kind of selectable tourism. Outings should be used both for arrival of tourists from vicinal towns, and for conceptualizing the more meaningful, more functional and high quality content of residing of all guests, as well as for organizing active vacations and recreation in the nature of local population.

Certain spatial reconstructions within the housing-estates should be conducted in the forthcoming period, based on utility company equipment, together with the observance of integral protection concept (protection of nature in its entirety) during any planned activity with the minimum of unplanned construction. Special attention should be paid to the development of sustainable tourism on the SNR "Deliblato Sands" area, together with its environment. 


\section{Acknowledgements}

The paper is the result of the research within the project no. 176008 funded by the Ministry of Education and Science of the Republic of Serbia.

\section{References}

Adamiak, C., Pitkanen, K. and Lehtonen, O. (2017). Seasonal residence and counterurbanization: the role of second homes in population redistribution in Finland, GeoJournal, 82, pp 1035-1050.

Back, A., Marjavaara, R. (2017). Mapping an invisible population: the uneven geography of second-home tourism, Tourism Geographies, 19:4, pp 595-611.

Bakić, O., Tomić Hrabovski E., Kovačević, J., Andrejević, S., Plavša, J., Mićić Maksin, M., Muhi, B., Katić, A., Ravnikar, D. i Muharemović, S. (20102011). Identifikacija potencijala za razvoj turizma na području SRP Deliblatska peščara - Studija, Sremska Kamenica: Fakultet poslovne ekonomije.

Brida, J.G., Osti, L. and Santifaller, E. (2011). Second homes and the need for policy planning, Tourismos: An international multidisciplinary journal of tourism, 6, Number 1, pp 141-163.

Charles-Edwards, E., Bell, M. (2015). Seasonal flux in Australia's population geography: Linking space and time. Population, Space and Place, 21 (2), pp 103-123.

Farstad, M. (2013). Local residents' valuation of second home owners' presence in a sparsely inhabited area. Scandinavian Journal of Hospitality and Tourism, 13(4), pp 317-331.

Farstad, M., Ryeab, J. F. (2013). Second home owners, locals and their perspectives on rural development, Journal of Rural Studies, 30, pp 41-51.

Hall, C. M. (2014). Second home tourism: An international review. Tourism Review International, 18(3), pp 115-135.

Hiltunen, M. J., Pitkanen, K., Vepsalainen, M. and Hall, C. M. (2013). Second home tourism in Finland: Current trends and eco-social impacts. In Z. Roca (Ed.), Second homes in Europe: Lifestyle issues and policy responses (pp. 165-200). Farnham: Ashgate.

Koderman, M. (2017). Second homes in protected areas of Slovenia - The case of the Triglav national park. In Filipović, D., Gosar, A., Koderman, M., Đurđić, S. (Edit.): Tourism in protected areas of nature in Serbia and Slovenia, (87-101). Belgarde: University of Belgrade - Faculty of Geography. 
Kovačev, N., Romelić, J., Pivac, T. i Lukić, T. (2014). Trips as Primary and Associated Forms of Other Tourist Deliblato Sands Movement, Researches Review DGTH, 43(2), 130-147.

Lardiés-Bosque, R. (2017). Residential mobility, second homes and quality of life: Consequences of moving out from the city of Madrid, Bulletin of Geography. Socio-economic Series, 37, pp 51-62.

Marjavaara, R., Lundholm, E. (2016). Does second-home ownership trigger migration in later life? Population, Space and Place, 22(3), pp 228-240.

Miletić, G.M., Žmuk, B. i Mišetić, R. (2017). Second homes and local socioeconomic development: the case of Croatia. Journal of Housing and the Built Environment, 32, pp 1-18.

Pavlović, S. (2017). Apartments for vacation and recreation in the function of tourism of the protected natural resources in Serbia. In Filipović, D., Gosar, A., Koderman, M., Đurđić, S. (Edit.): Tourism in protected areas of nature in Serbia and Slovenia, (73-87). Belgarde: University of Belgrade Faculty of Geography.

Savezni zavod za statistiku. (1984). Popis stanovništva, domaćinstava i stanova u 1981. godini. Tabela 196. (str. 739-1321), Stambene jedinice po broju i površini, prema korišćenju, svojini, godini izgradnje, opremljenosti instalacijama i nastanjenosti (SFRJ, SR i SAP, opštine i naselja). Beograd: Socijalistička Federativna Republika Jugoslavija, Savezni zavod za statistiku.

Savezni zavod za statistiku. (1994). Popis'91. Stanovi. Korišćenje i nastanjena lica. Podaci po naseljima, Knjiga 1. Beograd: Savezni zavod za statistiku.

Velvin, J., Kvikstad M. T., Drag, E. and Krogh, E. (2013). The Impact of Second Home Tourism on Local Economic Development in Rural Areas in Norway, Tourism Economics, 19(3), pp 689-705.

Winkler, R., Deller, S. and Marcouiller, D. (2015). Recreational housing and community development: Atriple bottom line approach. Growth and Change, 46(3), pp 481-500.

http://www.pur.rs/, accessed: 24.06.2017.

Републички завод за статистику. (2004). Попис становништва, домаћинстава и станова у 2002. Станови. Коришћење и настањена лица. Подаци по насељима. Књига 1. Београд: Републички завод за статистику.

Републички завод за статистику. (2013). Попис становништва, домаћинстава и станова 2011 у Републици Србији. Станови. Број и површина 
стамбених јединица. Подаци по насељима. Књига 22. Београд: Републички завод за статистику.

*** (2006). Просторни план подручја посебне намене Специјалног резервата природе Делиблатска пешчара, Нови Сад: Покрајински секретаријат за архитектуру, урбанизам и градитељство, Аутономна покрајина Војводине.

*** (2008). Просторни план општине Бела Црква, Нови Сад: ЈП Завод за урбанизам Војводине-Нови Сад.

*** (2009). Просторни план општине Вршац, Нови Сад: ЈП Завод за урбанизам Војводине-Нови Сад.

*** (2009). Просторни план општине-Града Панчева, Панчево: ЈП „Дирекција за изградњу и уређење Панчева“ , Сектор за просторно и урбанистичко планирање и пројектовање.

*** (2012). Просторни план општине Алибунар, Нови Сад: ЈП Завод за урбанизам Војводине-Нови Сад.

*** (2012). Просторни план општине Ковин, Нови Сад: ЈП Завод за урбанизам Војводине-Нови Сад.

*** (2016). План генералне регулације насеља Бела Црква-Нацрт Плана, Бела Црква: ЈП Завод за урбанизам Војводине-Нови Сад. 